\title{
Associations of benthic fauna with different rock types, and evidence of changing effects during succession
}

\author{
Kiran Liversage ${ }^{1,3}$, Nathan Janetzki ${ }^{2}$, Kirsten Benkendorff ${ }^{1, *}$ \\ ${ }^{1}$ Marine Ecology Research Centre, School of Environment, Science and Engineering, Southern Cross University, PO Box 157, \\ Lismore, New South Wales 2480, Australia \\ ${ }^{2}$ School of Biological Sciences, Flinders University, GPO Box 2100, Adelaide, South Australia 5001, Australia \\ ${ }^{3}$ Present address: Natural Resources South East, Department of Environment, Water and Natural Resources, GPO Box 1046, \\ Mount Gambier, South Australia 5290, Australia
}

\begin{abstract}
The importance of the substratum to benthic species can vary depending on the material of its construction. Intertidal boulder reefs with different rock types often have distinct benthic assemblages, and their ecology is structured strongly by succession. Therefore, dynamics causing assemblage variability may involve an interaction of factors involved in succession with features of the substratum. The current experiments monitored 11 month successional trajectories of benthic invertebrates on 2 rock types (siltstone and limestone) with differing physical characteristics. Unmanipulated boulders in siltstone and limestone reefs had different assemblages, but when bare boulders of the non-native rock type were transplanted into reefs, assemblages developing on non-native boulders were in most ways similar to those on boulders of the reef's native rock type. A substratum-dependent variation in successional trajectories was observed for one taxon, the true limpet Notoacmea spp. Under specific conditions of rock type at the individual boulder scale and the wider reef scale, evidence was found of a consistent peak in abundance during early succession. Notoacmea spp. was also positively associated not only with siltstone reefs but also with individual siltstone boulders, suggesting an effect of rock type at the boulder scale. Although processes occurring at scales encompassing whole reefs mostly dictate how these assemblages are associated with rock type, some species are affected by rock type at the boulder scale, and the effect can vary during succession. For such species, successional processes and environmental factors need to be considered synergistically to understand spatial and temporal population variability.
\end{abstract}

KEY WORDS: Substrata $\cdot$ Boulder fields $\cdot$ Rocky intertidal $\cdot$ Molluscs $\cdot$ Notoacmea $\cdot$ Assemblage development Resale or republication not permitted without written consent of the publisher

\section{INTRODUCTION}

When resources used by species are made newly available, the ecological processes that commence are crucial in establishing subsequent patterns of biodiversity through time and space (Connell 1978, Sousa 1979, Platt \& Connell 2003). Many organisms rely on disturbances (Dayton 1971) or the creation of new habitat (e.g. Drake \& Mueller-Dombois 1993,
Tomascik et al. 1996) to provide resources necessary for survival. Available habitat will vary in usefulness according to features such as the material from which physical structures in the habitat are formed (e.g. Anderson \& Underwood 1994) and the arrangement of such structures at various spatial scales (e.g. Archambault \& Bourget 1996). Habitats also vary in usefulness depending on the extent that other species have already begun to exploit the newly avail- 
able resources (Underwood \& Anderson 1994) and on the life-history traits of the colonising species (Huston \& Smith 1987). Changes in biotic structure in newly available habitat can be deterministic in some cases (Palmer et al. 1997), but stochastic fluctuations of colonisation in other cases can result in unpredictable assemblage changes (Sousa 1984b, Underwood \& Anderson 1994, Palmer et al. 1997). Such variation is likely to complicate the detection of any associations between specific biotic and abiotic structure.

An important resource in many habitats is free space on a substratum. Features of the substratum can influence environmental conditions (Jackson 2010) and predation (Nelson \& Vance 1979, Anderson 2001) as well as species movement (Underwood \& Chapman 1989, Chapman 2000), attachment (Underwood \& Jernakoff 1981), feeding (Lubchenco 1983) and recruitment (Chabot \& Bourget 1988, Abelson \& Denny 1997). Species adapted for certain successional stages may use features unique to certain substrata. Although succession is known to vary between environmental contexts (e.g. Hansen 2002, Berntsson \& Jonsson 2003, Platt \& Connell 2003), including differing substrata (Underwood \& Anderson 1994, Donnegan \& Rebertus 1999), few studies have tested the possibility of separate and interactive effects of successional stage and the material composition of substrata occurring naturally in rocky marine habitats.

Rocky benthic species often live in close contact with the substratum, features of which can greatly influence their settlement. This has been widely studied for barnacles (Moore \& Kitching 1939, Chabot \& Bourget 1988), tubeworms (James \& Underwood 1994) and algae (McGuinness \& Underwood 1986). For species that are mobile as adults, features of the substrata can affect movement (Underwood \& Chapman 1989, Chapman 2000) and availability of algal food (Green et al. 2012). In addition, the mineralogy of rock can directly affect some species (Bavestrello et al. 2000, Guidetti et al. 2004). These studies suggest that rock type should be an important consideration during ecological investigations of rocky benthic communities.

Some rocky benthic species that are influenced by the substratum are also important contributors to patterns of ecological succession. For example, barnacles on intertidal rock platforms are often influenced by features of the substratum (Chabot \& Bourget 1988, Holmes et al. 1997) and also play important roles during early succession (Chalmer 1982, Farrell 1991). Intertidal boulder reefs are another habitat where species are often influenced by succession
(Sousa 1979) and rock type (McGuinness \& Underwood 1986, James \& Underwood 1994, Liversage \& Benkendorff 2013). If rock type or other features of the substratum influence species in boulder reefs, there is the potential for succession across reefs of multiple rock types to be controlled by this factor.

The present study investigated differences in species assemblages occurring on boulders from intertidal reefs consisting of 2 rock types (limestone and siltstone) in South Australia over 11 mo. Within the reefs, we investigated assemblages occurring on unmanipulated boulders of the rock type native to the reef (hereafter referred to as 'control' boulders), and on translocated bare boulders both of the native rock type and the alternative type. We considered 4 questions (Q1-4):

\section{Q1: Do assemblages on siltstone and limestone reefs differ?}

Associations between specific species assemblages and rock types occur in many marine habitats at scales that encompass different geographical locations (Davidson \& Chadderton 1994, Bavestrello et al. 2000, Guidetti et al. 2004, Green et al. 2012, Liversage \& Benkendorff 2013). Similar associations may occur in these South Australian reefs, in which case we would expect that assemblages on control boulders in siltstone and limestone reefs would be significantly different.

\section{Q2: Do assemblages on initially bare and unmanipulated boulders converge over time?}

Assemblages on natural, unmanipulated boulders may remain relatively stable over time or may fluctuate (McGuinness \& Underwood 1986), while on initially bare boulders, a process of successional development can be expected (Sousa 1984a). Trajectories of change on these 2 assemblage types may involve assemblage convergence within our 11 mo timeframe, or the assemblages may remain distinct, and any outcome of convergence or divergence may vary between reef types. If convergence occurs, this would provide evidence that disturbed assemblages or those developing on initially bare substrata can, after a certain period of development, accurately represent those on unmanipulated substrata. We hypothesised that the initially different assemblages on control and translocated boulders of the same rock type would become more similar over time. This experiment encom- 
passed siltstone and limestone reefs to determine if trajectories of assemblage change interact not only with the assemblage types but also reef type.

\section{Q3: Do assemblages differ between rock types on the scale of individual boulders?}

Differences in assemblages among reef types may be caused by aspects of rock type important at the individual boulder scale or by factors that vary at the larger reef scale. We investigated whether dynamics causing different assemblages were operating at the boulder scale and hypothesized that assemblages developing on bare boulders within reefs would differ between the 2 rock types.

\section{Q4: Does succession on siltstone and limestone differ at the level of reefs or boulders?}

Effects of rock type may interact with the stage of assemblage development, indicating a divergence in successional trajectories between rock types (Pickett et al. 1987). If this were true, then changes over time would be expected in assemblage structure and individual species abundances on new substrata, and the changes should be consistent among random locations but dissimilar on boulders of different rock type within and/or between different reef types.

Alternatively to all these predictions, the supply of recruits and adult immigrants might be idiosyncratic. Boulders with identical rock type may be colonised by dissimilar assemblages at all stages of colonisation, changes may be dissimilar among locations, and we would not expect to find any determinism of effects from rock type. To answer these questions mensurative and manipulative experiments were done involving comparisons of assemblages on control boulders and the monitoring of assemblages over 11 mo after reciprocal translocation of limestone and siltstone boulders on replicate reefs consisting of the 2 rock types.

\section{MATERIALS AND METHODS}

\section{Locations of experiments}

The geologically diverse Fleurieu Peninsula (South Australia) has reefs consisting of numerous sedimentary rock types including pre-Cambrian era siltstones and younger fossiliferous limestones (Hasenohr \&
Corbett 1986). Experiments were done at the locations Myponga Beach (35 $\left.22^{\prime} \mathrm{S}, 138^{\circ} 23^{\prime} \mathrm{E}\right)$ and Marino Rocks $\left(35^{\circ} 02^{\prime} \mathrm{S}, 138^{\circ} 30^{\prime} \mathrm{E}\right)$, which have siltstone reefs, and at Blanche Point ( $\left.35^{\circ} 14^{\prime} \mathrm{S}, 138^{\circ} 27^{\prime} \mathrm{E}\right)$ and Southport $\left(35^{\circ} 10^{\prime} \mathrm{S}, 138^{\circ} 27^{\prime} \mathrm{E}\right)$, which have limestone ones. The locations were roughly evenly distributed along a relatively straight, sheltered coastline and had similar hydrodynamic conditions and human pressures.

\section{Methods for testing whether assemblages in siltstone and limestone reefs differ}

For this test, a mensurative experiment was done during low tides $(<0.6 \mathrm{~m})$ in November 2009 and February 2010 (austral late-spring and summer). Ten boulders at each location were selected by walking a random distance along a transect parallel to the shore and selecting the nearest boulder with a length or width dimension of 30 to $50 \mathrm{~cm}$, a size that can be readily overturned and manipulated. Boulder uppersides and undersides can have different species assemblages (McGuinness \& Underwood 1986), so counts of macrofauna from these positions were kept separate. The underside of a boulder was defined as the surface in contact with the substratum when placed in the reef, and the upperside was the entire remaining exposed surface. Individuals found underneath the boulder on the substratum on which it was resting were included with the underside data. Only macroscopic individuals were counted that could be measured in situ without damaging the habitat. Individuals $<5 \mathrm{~mm}$ were not counted as they generally could not be identified in the field. A species complex of Eogastropoda, Notoacmea flammea, N. mayi and $N$. alta, could not be readily identified in the field (Ponder \& Creese 1980), so all species in the Notoacmea genus were grouped.

Multivariate permutational analysis of variance (PERMANOVA) was used to compare assemblages and test the null-hypothesis of no difference between control boulders of the different reef types. BrayCurtis resemblances were calculated using the PRIMER v6 software package (Plymouth Marine Laboratory, UK). The factors were Reef type (siltstone or limestone; fixed), Time (November or February; random) and Location $($ random $;$ nested in Reef type $\times$ Time). Location refers to the 2 sampled locations nested within each reef type. Permutations of residuals were done under a reduced model with 9999 permutations. Square-root transformations were applied before analysis to down-weigh contributions from numeri- 
cally dominant species, and a dummy variable of value 1 was added because of sparsity of values among samples (Anderson et al. 2008). Monte Carlo p-values were used in cases in which the terms had too few unique permutations $(<100)$ for a meaningful test (Anderson et al. 2008). In these and all subsequent analyses, when the p-values of interaction terms that included random factors were $>0.25$, the terms were eliminated from the analysis to provide a more powerful test for the relevant null hypotheses (Underwood 1997). Principal coordinate analysis (Anderson et al. 2008) was used to produce scatter plots to visually represent multivariate differences among the treatments. The species that contributed to differences between treatments were identified using similarity percentages (SIMPER).

\section{Methods for testing convergence, boulder-scale differences and successional patterns}

To address the remaining questions, 11 mo patterns of macrofaunal colonisation were measured on control boulders at each location and also on bare boulders added to the reefs which were of similar rock type to the reef and of the alternate rock type. Translocated boulders were sourced from a single location of either rock type to overcome any confounding from location-specific mineralogical variability. Sixty boulders each of siltstone and limestone were haphazardly collected from Marino Rocks and Southport, all of length 30 to $50 \mathrm{~cm}$ and ovoid in shape. The boulders were taken from the upper intertidal shore where they were less likely to harbour existing macrofauna and/or biofilm that may confound results. A tag was attached to the upperside of each boulder with glue, and a number was marked with nail polish.

Physical attributes of the collected boulders were measured because they may differ between rock types and influence assemblage structure. Surface area was measured by counting $\mathrm{cm}^{2}$ area grids on an inelastic net placed over each boulder (Kuklinski \& Barnes 2008). Surface rugosity was measured using a modified version of the technique from Wilding et al. (2010); on 3 areas on each boulder, a piece of string was closely fitted to the boulder's surface contours, and ratios of the surface linear length to the surface contour length produced rugosity indices between 0 and 1 (indices approaching 1 are almost flat, and lower values are more rugose; Wilding et al. 2010). We also counted all cracks and depressions of at least $13 \mathrm{~mm}$ width and depth because they can be used as microhabitats for common gastropods and provide a biologically meaningful measurement of surface heterogeneity (McGuinness \& Underwood 1986). Means of these variables were compared between boulder types using 1-way ANOVA.

Boulder translocations were done in November 2009. In the mid-low shore at each location, 15 randomly allocated boulders of the same rock type as the reef and 15 of the alternate rock type were placed $10 \mathrm{~m}$ apart along transects running parallel to the shore. Siltstone and limestone boulders were alternatively placed along the transects and positioned similarly to natural boulders so factors such as the surrounding water flow would be comparable (Guichard \& Bourget 1998). This experiment was only initiated during summer, so the results only relate to substrata made available in that season. Counts of macrofauna were made 1 mo later from 5 randomly chosen boulders of each rock type and also from 5 co-occurring, randomly selected control boulders. After 4 mo of colonisation, 5 of the remaining translocated boulders of each rock type at each location were sampled, and the last 5 were sampled after 11 mo, along with 5 control boulders at each time.

Two separate analysis designs were used to answer Questions 2 to 4 (see 'Introduction'). For Question 2, we hypothesised that within $11 \mathrm{mo}$, initially bare boulders would develop assemblages and abundances that are similar to those on control boulders such that no significant difference in final communities would be detected. The null hypothesis was tested using PERMANOVA for assemblages and ANOVA for individual species, with the analyses including 3 fixed factors: Reef type (siltstone and limestone), Boulder treatment (control and initially bare boulders of the same rock type as the reef) and Time (boulders sampled after 1, 4 and $11 \mathrm{mo}$ ). SNK and PERMANOVA pairwise tests were used to test for effects of Boulder treatment and Time within both reef types. Different locations were included as a random factor nested in reef type.

To answer Question 3, we investigated whether different assemblages will develop between initially bare boulders of the 2 rock types. The null hypothesis of no significant difference was tested using the same factors as the previous design, except for the Boulder treatment factor, control boulders were not included, and initially bare boulders of both rock types were included for each location. These same factors were also used to answer Question 4, by investigating if successional trajectories differ between rock types, e.g. if assemblages develop more quickly or slowly on a certain rock type or if patterns indicative of sequential 
succession (Huston \& Smith 1987) occur on one rocktype but not the other. For each species, we hypothesised that Boulder treatment and/or Reef type would interact with Time, as this would indicate a difference in successional pathways between rock types.

Multivariate data of mobile species assemblages and univariate data of abundances of common species were analysed separately for boulder upper- and under-sides. Multivariate data were analysed with Bray-Curtis resemblances in PERMANOVA, and univariate abundance data were analysed using ANOVA in GMAV5 (EICC, The University of Sydney). The assemblage and individual species data from the initially bare boulders occurring in the reefs of their native rock type were used in both of the 2 analysis designs. To compensate for increased Type I error when performing multiple tests that include the same data (in this case, 2 tests for each assemblage/species), a Bonferroni correction of $1 / 2$ was applied to the statistical significance level alpha of 0.05 (see Cabin \& Mitchell 2000). To balance probabilities of encountering Type I and Type II errors in this type of experiment (Nakagawa 2004), no further alterations were made to the alpha values associated with multiple tests to address the same hypotheses using multivariate analyses on the community assemblage in addition to univariate analyses on species abundance data. Variances of data from most species were initially significantly heterogenous (tested using Cochran's test), so $\ln (x+1)$ transformations were applied for all species. This reduced variance heterogeneity to levels that were no longer significant for all species except Nerita atramentosa on top of boulders, so these analyses may have increased Type I error (Underwood 1997). The barnacle Chthamalus antennatus was extremely overdispersed among boulders, so analyses were done using dispersion weighting with PERMANOVA to provide a more meaningful analysis (Clarke et al. 2006). This species was not found on translocated boulders after $1 \mathrm{mo}$, so in the analyses to answer Q3 and Q4, only data from 4 mo and 11 mo were included. Euclidean distance was the measure used to calculate resemblances of these univariate data (Anderson et al. 2008).

\section{RESULTS}

\section{Q1: Do assemblages on siltstone and limestone reefs differ?}

Mobile assemblages were mostly comprised of 3 taxa: the true limpets Notoacmea spp., the false

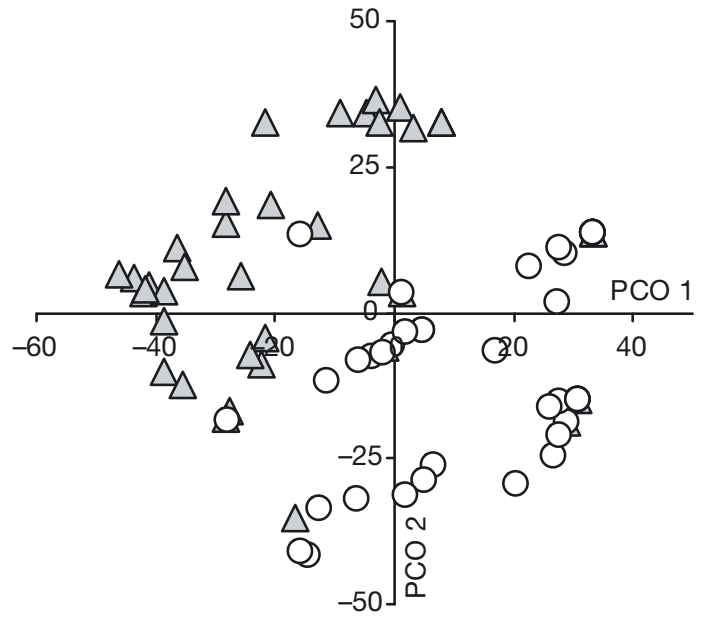

Fig. 1. Constrained principal coordinates plot of mobile assemblages underneath boulders in reefs of siltstone $(\Delta)$ and limestone $(\mathrm{O})$

limpet Siphonaria diemenensis and the nerite Nerita atramentosa. Also common underneath boulders was the crab Ozius truncatus. In most reefs, $S$. diemenensis populations were aggregated on only a few boulders. Another 15 mobile species were observed less commonly (see Table 1). The only sessile species found on the boulders in any considerable abundance was the barnacle Chthamalus antennatus.

Mobile assemblages under boulders differed between siltstone and limestone reefs (Fig. 1, Table 2) mostly because of the greater Nerita atramentosa and Notoacmea spp. and lower Ozius truncatus abundances in siltstone reefs (Table 1). On tops of boulders, no difference between reef types was detected (Table 2).

\section{Q2: Do assemblages on initially bare and unmanipulated boulders converge over time?}

The collected limestone and siltstone boulders used as the initially bare boulders in this experiment had differing physical attributes. Surface areas were similar (ANOVA, $\left.F_{(1,118)}=0.13, p>0.5\right)$, but the limestone boulders had significantly greater surface rugosity $\left(F_{(1,118)}=57.1, \mathrm{p}<0.001\right.$; Fig. $\left.2 \mathrm{a}\right)$ and much greater numbers of microhabitats $\left(F_{(1,118)}=81.2, \mathrm{p}<\right.$ 0.001; Fig. 2b).

The factors Boulder treatment and Reef type had interactive effects when assemblages underneath initially bare and control boulders were compared (Table 3a). Using PERMANOVA pairwise compar- 
Table 1. Contributions of species to measures of dissimilarity, calculated in PRIMER v6, between assemblages underneath boulders in siltstone and limestone reefs. Data were square-root transformed for the analysis, but the mean abundances are displayed here untransformed. The dissimilarity:standard deviation ratio indicates the reliability of the species to differentiate between groups, with a value $>1$ considered a reliable indicator

\begin{tabular}{|c|c|c|c|c|}
\hline \multirow[t]{2}{*}{ Species } & \multicolumn{2}{|c|}{ Mean abundance on boulders from: } & \multirow{2}{*}{$\begin{array}{c}\text { Dissimilarity:SD } \\
\text { ratio }\end{array}$} & \multirow{2}{*}{$\begin{array}{l}\% \text { contribution } \\
\text { to dissimilarity }\end{array}$} \\
\hline & Siltstone reefs & Limestone reefs & & \\
\hline Nerita atramentosa & 2.75 & 0.08 & 1.22 & 28.61 \\
\hline Notoacmea spp. & 5.33 & 1.2 & 1.1 & 28.33 \\
\hline Ozius truncatus & 0.45 & 0.65 & 0.71 & 14.91 \\
\hline Diloma concamerata & 0.83 & 0 & 0.5 & 5.89 \\
\hline Aulactinia veratra & 0 & 0.6 & 0.37 & 4.65 \\
\hline Bembicium vittatum & 0.05 & 0.18 & 0.39 & 4.27 \\
\hline Siphonaria diemenensis & 0 & 0.1 & 0.27 & 2.4 \\
\hline Ischnochiton elongatus & 0 & 0.15 & 0.29 & 1.98 \\
\hline Austrocochlea porcata & 0 & 0.08 & 0.22 & 1.78 \\
\hline Cellana tramoserica & 0.13 & 0.03 & 0.25 & 1.7 \\
\hline Isanemonia australis & 0 & 0.13 & 0.27 & 1.66 \\
\hline Turbo undulatus & 0 & 0.13 & 0.21 & 1.45 \\
\hline Cantharidella balteata & 0.03 & 0 & 0.15 & 0.84 \\
\hline Rissoina spp. & 0.03 & 0 & 0.16 & 0.44 \\
\hline Actinia tenebrosa & 0.08 & 0 & 0.16 & 0.43 \\
\hline Cellana solida & 0 & 0.03 & 0.15 & 0.42 \\
\hline Lepsiella vinosa & 0.03 & 0 & 0.16 & 0.25 \\
\hline
\end{tabular}

Table 2. PERMANOVA of mobile species assemblages underneath and on top of boulders sampled from siltstone and limestone reef types at 2 random times and at 2 random locations within each reef type. ${ }^{*} \mathrm{p}<0.05,{ }^{* *} \mathrm{p}<0.01,{ }^{* * *} \mathrm{p}<$ 0.001. (-) eliminated term; Re: Reef type; Ti: Time; Lo: location

\begin{tabular}{|lrrcrc|}
\hline \multirow{2}{*}{ Source } & \multirow{2}{*}{ df } & \multicolumn{2}{c}{ Underneath } & \multicolumn{2}{c|}{ On top } \\
& & MS & $F$ & MS & $F$ \\
\hline $\mathrm{Ti}$ & 1 & 7122 & 1.96 & 4620 & 0.64 \\
$\mathrm{Re}$ & 1 & 23717 & $13.31^{*}$ & 14971 & 2.08 \\
$\mathrm{Ti} \times \mathrm{Re}$ & 1 & - & & - & \\
$\mathrm{Lo}(\mathrm{Ti} \times \mathrm{Re})$ & 4 & 3642 & $0.49^{* * *}$ & 7201 & $5.88^{* * *}$ \\
$\operatorname{Res}$ & 73 & 1182 & & 1226 & \\
& & & & & \\
\hline
\end{tabular}

isons, no significant differences were found between initially bare vs. control boulders in reefs of siltstone (Fig. 3a) or limestone (Fig. 3b), but the assemblages under both boulder types did differ between reef types. There were changes in underside assemblages through time, but they were variable among random locations and not influenced by the boulder treatment or reef type (Table 3a). On top of boulders, differences between control and initially bare boulders varied inconsistently among times and random locations (Table $3 \mathrm{~b}$ ) with no significant difference according to reef type.

Abundances of Notoacmea spp. underneath and on top of boulders did not differ significantly between
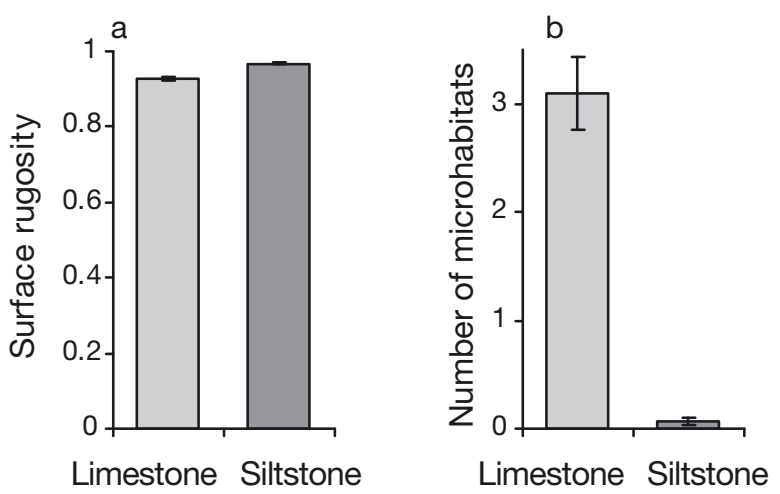

Fig. 2. Differences in mean $( \pm 1 \mathrm{SE})(\mathrm{a})$ surface rugosity index and (b) number of microhabitats per boulder on bare limestone and siltstone boulders collected for translocation to boulder reefs to act as substrata for colonisation. The surface rugosity index can range from 0 to 1 , with indices approaching 1 indicating an almost flat surface, and lower values indicating more rugosity. Microhabitats on boulders were cracks or depressions with a width and depth of at least $13 \mathrm{~mm}$

control and initially bare boulders (Table 3, Fig. 4a,b). There was no interaction between Boulder treatment and Time, but abundances did vary among sampling times at specific random locations (Table 3). Abundances of $N$. atramentosa did not change significantly over time, but interactions were found between Boulder treatment and Reef type (Table 3). SNK tests showed there were significantly more $N$. 
atramentosa in siltstone reefs compared to limestone underneath (Fig. 4c) and on top of boulders (Fig. 4d), and within siltstone reefs, they were more abundant on control vs. initially bare boulders (Table 3, Fig. 3c,d). Ozius truncatus abundances did not vary significantly according to any factors (Table 3a). Greater abundances of Chthamalus antennatus occurred underneath boulders in limestone (mean $=3.12, \mathrm{SE}=$ 1.64) compared to siltstone reefs (mean $=0.28, \mathrm{SE}=$ 0.16 ; Table 3a), but the abundance of this species was not affected by Boulder treatment or Time. On boulder uppersides, only random spatial variation was detected (Table 3b).

\section{Q3: Do assemblages differ between rock types on the scale of individual boulders?}

Mobile species assemblages developing underneath and on top of boulders varied interactively and inconsistently between Time and Location, with no differences detected between limestone and siltstone boulders (Table 4). Abundances of Notoacmea spp. underneath boulders did vary significantly between the rock types but only at certain times and locations (Table 4a). SNK tests revealed that this occurred at Myponga Beach (Fig. 5a) and Blanche Point (Fig. 5b) at 4 mo and at Marino Rocks

Table 3. ANOVA of assemblages and abundances of species on (a) boulder undersides and (b) boulder uppersides from different treatments (control boulders and initially bare boulders) in reefs of siltstone and limestone sampled at 3 different times $(1,4$, and 11 mo after the beginning of the experiment). All factors were fixed except location nested in reef rock type. Homogeneity of variances was tested using Cochran's test on the $\ln (x+1)$ transformed data that was analysed by ANOVA on GMAV5. Cochran's test was not used for analyses of assemblages or for Chthamalus antennatus; these were analysed using PERMANOVA which is more robust to heterogenous variances. ${ }^{*} p<0.025,{ }^{* *} p<0.01,{ }^{* * *} p<0.001 .(-)$ eliminated term; Re: Reef rock type; Lo(Re): Location; Bo: Boulder treatment; Ti: Time

\begin{tabular}{|c|c|c|c|c|c|c|c|c|c|c|c|}
\hline \multirow[t]{2}{*}{ Source } & \multirow[t]{2}{*}{$\mathrm{df}$} & \multicolumn{2}{|c|}{$\begin{array}{c}\text { Mobile } \\
\text { assemblage }\end{array}$} & \multicolumn{2}{|c|}{$\begin{array}{c}\text { Notoacmea } \\
\text { spp. }\end{array}$} & \multicolumn{2}{|c|}{$\begin{array}{c}\text { Nerita } \\
\text { atramentosa }\end{array}$} & \multicolumn{2}{|c|}{$\begin{array}{c}\text { Ozius } \\
\text { truncatus }\end{array}$} & \multicolumn{2}{|c|}{$\begin{array}{l}\text { Chthamalus } \\
\text { antennatus }\end{array}$} \\
\hline & & MS & $F$ & MS & $F$ & MS & $F$ & MS & $F$ & MS & $F$ \\
\hline \multicolumn{12}{|c|}{ (a) Boulder undersides } \\
\hline $\operatorname{Re}$ & 1 & 23559 & $8.17^{* * *}$ & 13.00 & 6.93 & 13.44 & $412.86^{* *}$ & 0.98 & 6.90 & 0.20 & $35.96^{*}$ \\
\hline $\mathrm{Lo}(\mathrm{Re})$ & 2 & 2884 & $2.59^{* * *}$ & 1.87 & 3.51 & 0.03 & 0.12 & 0.14 & 0.76 & 0.01 & 0.06 \\
\hline Bo & 1 & 1044 & 0.94 & 0.18 & 0.34 & 0.43 & 1.57 & 0.28 & 1.50 & 0.05 & 0.60 \\
\hline $\mathrm{Ti}$ & 2 & 8782 & 1.65 & 15.31 & 1.80 & 0.10 & 0.38 & 0.07 & 0.37 & 0.10 & 1.17 \\
\hline $\mathrm{Bo} \times \mathrm{Ti}$ & 2 & 955 & 0.86 & 1.48 & 1.48 & 0.09 & 0.33 & 0.10 & 0.56 & 0.20 & 2.32 \\
\hline $\mathrm{Bo} \times \mathrm{Re}$ & 1 & 3173 & $2.85^{*}$ & 0.73 & 1.36 & 1.62 & $5.99^{*}$ & 0.34 & 1.82 & 0.08 & 0.92 \\
\hline $\mathrm{Ti} \times \mathrm{Re}$ & 2 & 2779 & 0.52 & 3.39 & 0.40 & 0.03 & 0.13 & 0.45 & 2.44 & 0.11 & 1.26 \\
\hline $\mathrm{Bo} \times \mathrm{Lo}(\mathrm{Re})$ & 2 & - & & - & & - & & - & & - & \\
\hline $\mathrm{Ti} \times \operatorname{Lo}(\operatorname{Re})$ & 4 & 5336 & $4.80^{* * *}$ & 8.50 & $15.90^{* * *}$ & - & & - & & - & \\
\hline $\mathrm{Bo} \times \mathrm{Ti} \times \mathrm{Re}$ & 2 & 1094 & 0.98 & 0.25 & 0.25 & 0.03 & 0.12 & 0.16 & 0.88 & 0.17 & 1.95 \\
\hline Bo $\times \mathrm{Ti} \times$ Lo(Re) & 4 & - & & 1.00 & 1.87 & - & & - & & - & \\
\hline \multirow[t]{2}{*}{ Res } & 96 & 1112 & & 0.54 & & 0.28 & & 0.19 & & 0.09 & \\
\hline & & & & \multicolumn{2}{|c|}{$\begin{array}{c}\text { Cochran's test } \\
\qquad \begin{array}{c}C=0.15 \\
\text { p }>0.05\end{array}\end{array}$} & \multicolumn{2}{|c|}{$\begin{array}{c}\text { Cochran's test } \\
C=0.11 \\
\mathrm{p}>0.05\end{array}$} & \multicolumn{2}{|c|}{$\begin{array}{c}\text { Cochran's test } \\
C=0.16 \\
\mathrm{p}>0.05\end{array}$} & & \\
\hline \multicolumn{12}{|c|}{ (b) Boulder uppersides } \\
\hline $\mathrm{Re}$ & 1 & 15545 & 2.70 & 8.70 & 20.79 & 2.79 & $452.23^{* *}$ & & & 1.84 & 1.17 \\
\hline $\mathrm{Lo}(\mathrm{Re})$ & 2 & 5757 & $5.59^{* * *}$ & 0.42 & 0.68 & 0.01 & 0.05 & & & 1.57 & $4.27^{* *}$ \\
\hline Bo & 1 & 4337 & 2.35 & 0.53 & 0.87 & 0.93 & $7.53^{* *}$ & & & 0.72 & 1.96 \\
\hline $\mathrm{Ti}$ & 2 & 4210 & 1.34 & 4.64 & 1.20 & 0.28 & 1.60 & & & 0.88 & 2.40 \\
\hline $\mathrm{Bo} \times \mathrm{Ti}$ & 2 & 1048 & 0.49 & 0.18 & 0.29 & 0.06 & 0.23 & & & 0.32 & 0.87 \\
\hline $\mathrm{Bo} \times \mathrm{Re}$ & 1 & 3109 & 1.68 & 1.21 & 1.97 & 0.70 & $5.68^{*}$ & & & 0.77 & 2.10 \\
\hline $\mathrm{Ti} \times \mathrm{Re}$ & 2 & 2031 & 0.64 & 2.29 & 0.59 & 0.16 & 0.93 & & & 0.58 & 1.58 \\
\hline $\mathrm{Bo} \times \mathrm{Lo}(\mathrm{Re})$ & 2 & 1847 & 1.79 & - & & - & & & & - & \\
\hline $\mathrm{Ti} \times \mathrm{Lo}(\mathrm{Re})$ & 4 & 3149 & $3.06^{* * *}$ & 3.88 & $6.31^{* * *}$ & 0.17 & 1.40 & & & - & \\
\hline $\mathrm{Bo} \times \mathrm{Ti} \times \mathrm{Re}$ & 2 & 2625 & 1.22 & 2.24 & 3.65 & 0.02 & 0.06 & & & 0.16 & 0.43 \\
\hline $\mathrm{Bo} \times \mathrm{Ti} \times \operatorname{Lo}(\mathrm{Re})$ & 4 & 2161 & $2.10^{* *}$ & - & & 0.28 & 2.30 & & & - & \\
\hline \multirow[t]{2}{*}{ Res } & \multirow[t]{2}{*}{96} & \multirow{2}{*}{\multicolumn{2}{|c|}{1030}} & \multicolumn{2}{|l|}{0.63} & \multicolumn{2}{|l|}{0.13} & & & \multicolumn{2}{|l|}{0.37} \\
\hline & & & & \multicolumn{2}{|c|}{$\begin{array}{c}\text { Cochran's test } \\
C=0.15 \\
\mathrm{p}>0.05\end{array}$} & \multicolumn{2}{|c|}{$\begin{array}{c}\text { Cochran's test } \\
C=0.22 \\
\mathrm{p}<0.01\end{array}$} & & & & \\
\hline
\end{tabular}



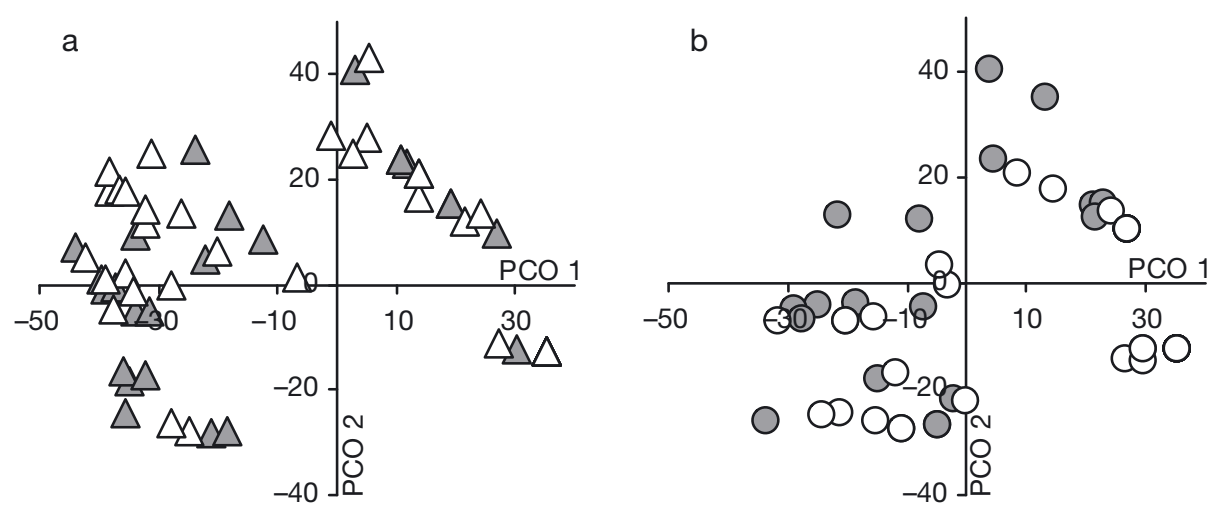

Fig. 3. Constrained principal coordinates plot of mobile assemblages underneath (white fill) control boulders and (grey fill) initially bare boulders in reefs of (a) siltstone and (b) limestone
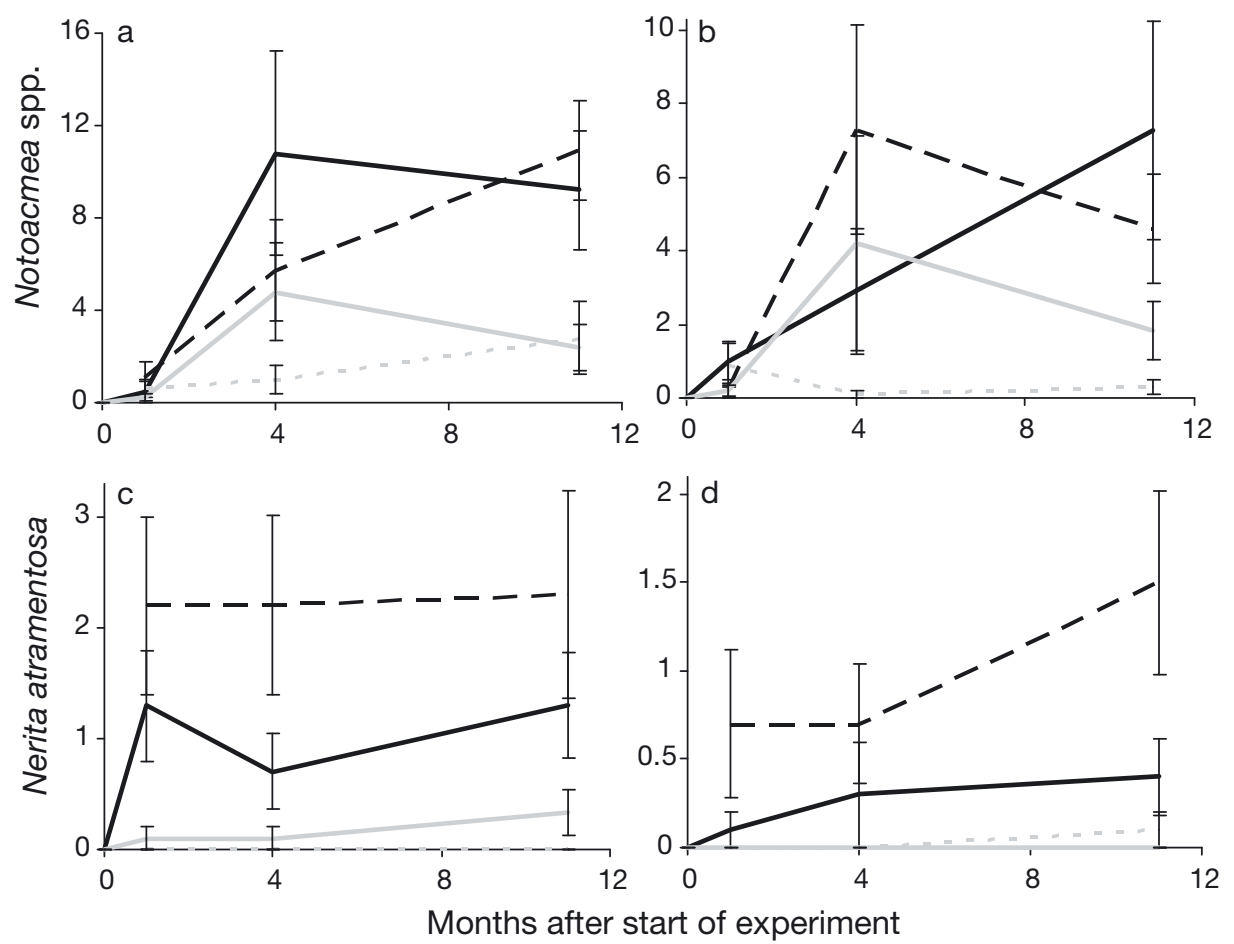

Fig. 4. Differences in mean $( \pm 1 \mathrm{SE})$ numbers of invertebrates on (black line) initially bare siltstone boulders added to siltstone reefs, (solid grey line) initially bare limestone boulders added to limestone reefs and control boulders in (dashed black line) siltstone reefs and (dotted grey line) limestone reefs; Notoacemea spp. (a) underneath and (b) on top of boulders and Nerita atramentosa (c) underneath and (d) on top of boulders. Data shown are means of 2 random locations of each rock type; $\mathrm{n}=5$ replicate boulders in each location

after 11 mo (Fig. 5c). In all cases, there were significantly greater abundances on siltstone than on limestone boulders (Fig. 5). For Notoacmea spp. on top of boulders, ANOVA indicated an interaction among all 3 fixed factors (Table $4 \mathrm{~b}$ ). SNK tests revealed that greater abundances were on top of siltstone boulders in siltstone reefs after 11 mo compared to the other times (Fig. 5d) and that in siltstone reefs, significantly greater abundances were on siltstone compared to limestone boulders (Fig. 5d). No differences were detected between boulder types in limestone reefs.

No significant effects of rock type were observed for abundances of $N$. atramentosa on initially bare boulders, and patterns of variation among different lengths of colonisation were not consistent (Table 4). Similarly, abundances of $O$. truncatus and $C$. antennatus did not differ between boulder 
types (Table 4). The only variation was between reef types for $C$. antennatus underneath boulders (Table 4a).

\section{Q4: Does succession on siltstone and limestone differ at the level of reefs or boulders?}

Seldom did Time $\times$ Boulder type/Reef type interactions occur that would indicate variability in successional patterns between rock types (Table 4). It appeared, however, that an exception to this trend was Notoacmea spp. on tops of boulders, whose abundances were found to vary interactively among all 3 fixed factors (Table 4b). SNK tests indicated that Notoacmea spp. abundances did not vary significantly among the 1, 4 and 11 mo samples, except for in one context: when occurring on tops of siltstone boulders in limestone reefs. When Notoacmea spp. populations were in this context, there was a peak in abundance after 4 mo that was greater than the abundances after 1 or 11 mo (Fig. 5d) and consistent among random locations. The abovementioned difference between Notoacmea spp. abundances on top of siltstone vs. limestone boulders after $11 \mathrm{mo}$ but not at the other times (Fig. 5d) also represented a divergence in successional trajectories, contrary to the null hypothesis for Question 4 regarding this genus.

Table 4. ANOVA of assemblages and abundances of species on (a) boulder undersides and (b) boulder uppersides that have different rock type (limestone or siltstone) in reefs of the 2 rock types sampled at 3 different times $(1,4$, and 11 mo after the beginning of the experiment). All factors were fixed except location nested in reef rock type. Homogeneity of variances was tested using Cochran's test on the $\ln (x+1)$ transformed data that was analysed by ANOVA on GMAV5. Cochran's test was not used for analyses of assemblages or for Chthamalus antennatus; these were analysed using PERMANOVA which is more robust to heterogenous variances. ${ }^{*} p<0.025,{ }^{* *} p<0.01,{ }^{* * *} p<0.001$. (-) eliminated term; Re: Reef rock type; Lo(Re): Location; Bo: Boulder treatment; Ti: Time

\begin{tabular}{|c|c|c|c|c|c|c|c|c|c|c|c|c|}
\hline \multirow[t]{2}{*}{ Source } & \multirow[t]{2}{*}{ df } & \multicolumn{2}{|c|}{$\begin{array}{c}\text { Mobile } \\
\text { assemblage }\end{array}$} & \multicolumn{2}{|c|}{$\begin{array}{c}\text { Notoacmea } \\
\text { spp. }\end{array}$} & \multicolumn{2}{|c|}{$\begin{array}{c}\text { Nerita } \\
\text { atramentosa }\end{array}$} & \multicolumn{2}{|c|}{$\begin{array}{c}\text { Ozius } \\
\text { truncatus }\end{array}$} & \multirow[t]{2}{*}{$\mathrm{df}$} & \multicolumn{2}{|c|}{$\begin{array}{l}\text { Chthamalus } \\
\text { antennatus }\end{array}$} \\
\hline & & MS & $F$ & MS & $F$ & MS & $F$ & MS & $F$ & & MS & $F$ \\
\hline \multicolumn{13}{|c|}{ (a) Boulder undersides } \\
\hline $\operatorname{Re}$ & 1 & 15096 & 5.26 & 0.84 & 0.34 & 7.15 & $58.50^{*}$ & 0.89 & 4.19 & 1 & 1.94 & $336.05^{* *}$ \\
\hline $\mathrm{Lo}(\mathrm{Re})$ & 2 & 2868 & $2.69^{* *}$ & 2.44 & $3.91^{*}$ & 0.12 & 0.58 & 0.21 & 2.31 & 2 & 0.01 & 0.01 \\
\hline Bo & 1 & 1776 & 1.66 & 3.43 & $5.49^{*}$ & 0.28 & 1.36 & 0.03 & 0.37 & 1 & 1.23 & 1.91 \\
\hline $\mathrm{Ti}$ & 2 & 14172 & 3.63 & 20.07 & 3.38 & 0.04 & 0.21 & 0.03 & 0.30 & 1 & 0.21 & 0.21 \\
\hline $\mathrm{Bo} \times \mathrm{Ti}$ & 2 & 764 & 0.51 & 0.30 & 0.16 & 0.30 & 0.57 & 0.16 & 1.79 & 1 & 0.79 & 1.23 \\
\hline $\mathrm{Bo} \times \mathrm{Re}$ & 1 & 1081 & 1.01 & 0.07 & 0.11 & 0.00 & 0.01 & 0.41 & 4.43 & 1 & 1.42 & 2.21 \\
\hline $\mathrm{Ti} \times \mathrm{Re}$ & 2 & 2137 & 0.55 & 2.56 & 0.43 & 0.10 & 0.49 & 0.08 & 0.82 & 1 & 0.41 & 0.41 \\
\hline Bo $\times \operatorname{Lo}(\operatorname{Re})$ & 2 & - & & - & & - & & - & & 2 & - & \\
\hline $\mathrm{Ti} \times \mathrm{Lo}(\mathrm{Re})$ & 4 & 3903 & $3.66^{* * *}$ & 5.93 & $9.49^{* * *}$ & - & & - & & 2 & 0.98 & 1.53 \\
\hline $\mathrm{Bo} \times \mathrm{Ti} \times \operatorname{Re}$ & 2 & 897 & 0.59 & 0.34 & 0.18 & 0.37 & 0.71 & 0.02 & 0.24 & 1 & 0.45 & 0.70 \\
\hline $\mathrm{Bo} \times \mathrm{Ti} \times \mathrm{Lo}(\mathrm{Re})$ & 4 & 1510 & 1.41 & 1.90 & $3.05^{*}$ & 0.53 & 2.53 & - & & 2 & - & \\
\hline \multirow[t]{2}{*}{ Res } & 96 & 104650 & & 0.64 & & 0.21 & & 0.09 & & 64 & 0.64 & \\
\hline & & & & \multicolumn{2}{|c|}{$\begin{array}{c}\text { Cochran's test } \\
\qquad \begin{array}{c}C=0.13 \\
\mathrm{p}\end{array}>0.05\end{array}$} & \multicolumn{2}{|c|}{$\begin{array}{c}\text { Cochran's test } \\
\qquad \begin{array}{c}C=0.15 \\
\text { p }>0.05\end{array}\end{array}$} & \multicolumn{2}{|c|}{$\begin{array}{c}\text { Cochran's test } \\
C=0.12 \\
p>0.05\end{array}$} & & & \\
\hline \multicolumn{13}{|c|}{ (b) Boulder uppersides } \\
\hline $\mathrm{Re}$ & 1 & 5390 & 1.70 & 1.54 & $44.79^{*}$ & 1.12 & 16.66 & & & 1 & 3.42 & 1.70 \\
\hline $\mathrm{Lo}(\mathrm{Re})$ & 2 & 3168 & $3.14^{* *}$ & 0.03 & 0.05 & 0.07 & 0.60 & & & 2 & 2.01 & 3.15 \\
\hline Bo & 1 & 1544 & 1.53 & 0.27 & 0.19 & 0.01 & 0.09 & & & 1 & 1.28 & 2.00 \\
\hline $\mathrm{Ti}$ & 2 & 5945 & 1.59 & 4.86 & 1.97 & 0.14 & 1.25 & & & 1 & 0.45 & 0.70 \\
\hline BoxTi & 2 & 478 & 0.47 & 0.36 & 0.54 & 0.02 & 0.19 & & & 1 & 0.00 & 0.00 \\
\hline BoxRe & 1 & 1285 & 1.27 & 1.26 & 0.86 & 0.12 & 1.12 & & & 1 & 1.56 & 2.45 \\
\hline $\mathrm{Ti} \times \mathrm{Re}$ & 2 & 1383 & 0.37 & 0.37 & 0.15 & 0.10 & 0.85 & & & 1 & 0.22 & 0.35 \\
\hline Bo $\times$ Lo $(\mathrm{Re})$ & 2 & - & & 1.46 & 2.22 & - & & & & 2 & - & \\
\hline $\mathrm{Ti} \times \operatorname{Lo}(\mathrm{Re})$ & 4 & 3732 & $3.70^{* * *}$ & 2.47 & $3.70^{* *}$ & - & & & & 2 & - & \\
\hline $\mathrm{Bo} \times \mathrm{Ti} \times \mathrm{Re}$ & 2 & 1694 & 1.68 & 2.55 & $3.87^{*}$ & 0.12 & 1.04 & & & 1 & 0.12 & 0.19 \\
\hline $\mathrm{Bo} \times \mathrm{Ti} \times \mathrm{Lo}(\mathrm{Re})$ & 4 & - & & - & & - & & & & 2 & - & \\
\hline \multirow[t]{4}{*}{ Res } & 96 & 102840 & & 0.66 & & 0.12 & & & & 64 & 0.64 & \\
\hline & & & & \multirow{3}{*}{\multicolumn{2}{|c|}{$\begin{array}{c}\text { Cochran's test } \\
\qquad \begin{array}{c}C=0.15 \\
\mathrm{p}>0.05\end{array}\end{array}$}} & \multirow{3}{*}{\multicolumn{2}{|c|}{$\begin{array}{c}\text { Cochran's test } \\
\qquad \begin{array}{c}C=0.23 \\
\mathrm{p}<0.01\end{array}\end{array}$}} & & & & & \\
\hline & & & & & & & & & & & & \\
\hline & & & & & & & & & & & & \\
\hline
\end{tabular}




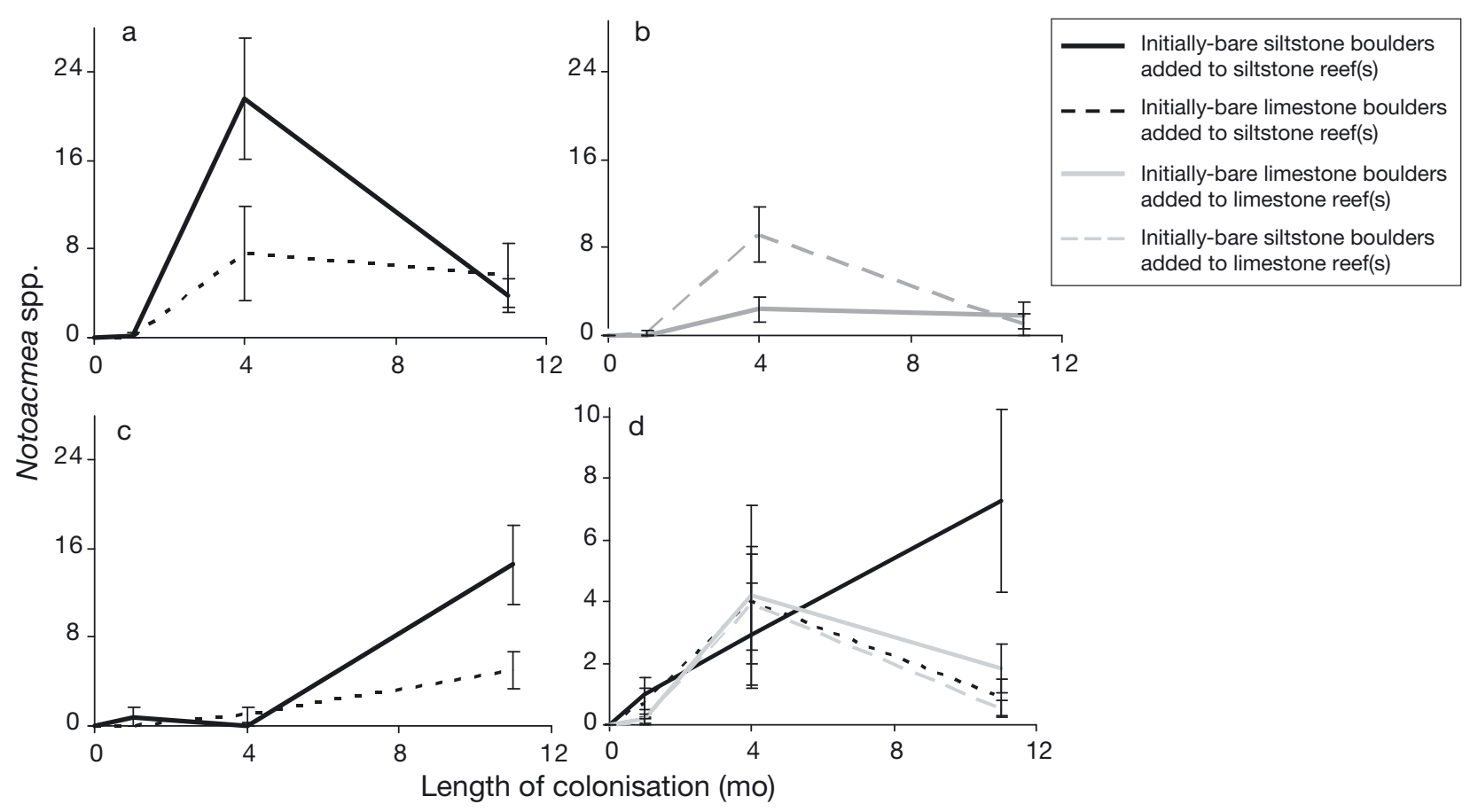

Fig. 5. Differences in mean $( \pm 1 \mathrm{SE})$ numbers of Notoacemea spp. colonising uppersides of initially bare boulders that were of (black line) siltstone rock type or (dotted black line) limestone placed in siltstone reefs as well as uppersides of initially bare boulders of (solid grey line) limestone rock type or (dashed grey line) of siltstone placed in limestone reefs. Data shown are trends from single locations at (a) Myponga Beach, (b) Blanche Point, (c) Marino Rocks and (d) the means of 2 locations of each rock type; $\mathrm{n}=5$ replicate boulders in each location

\section{DISCUSSION}

Benthic marine species often live in such close contact with the substratum and rely so heavily on the resources contained there that it is not unreasonable to assume that rock type, a fundamental feature of the substratum, should be important. However, evidence for an effect of rock type on benthic species is sparse. Some studies have found associations between biotic structure and rock type at scales encompassing different geographical locations (Vermeij 1971, Raimondi 1988, Davidson \& Chadderton 1994, Holmes et al. 1997, Bavestrello et al. 2000, Guidetti \& Cattaneo-Vietti 2002, Schiaparelli et al. 2003, Guidetti et al. 2004, Herbert \& Hawkins 2006, Green et al. 2012). The associations found at this scale, however, have rarely been confirmed at the boulder scale (e.g. McGuinness 1988), suggesting that the mechanisms causing these effects are more complex than simple species preferences for certain rock types. By experimenting on unmanipulated assemblages and those developing through succession, we attempted to answer 4 questions about how assemblages might develop on boulders in different contexts of rock type.

\section{Q1: Do assemblages on siltstone and limestone reefs differ?}

In these South Australian boulder reefs, assemblages of mobile species under boulders were unique according to the rock type of the reef (although this was only true underneath and not on top of boulders), which has similarly been found in other marine habitats (Raimondi 1988, Holmes et al. 1997, Bavestrello et al. 2000, Schiaparelli et al. 2003, Herbert \& Hawkins 2006). The differing rock type amongst reefs is only one possible mechanism that may be responsible for this, as other environmental features that vary among reefs of different rock type may be associated with the biotic variables. For example, the reef types may vary in the composition of the matrix (e.g. sand, shell grit or pebbles; Le Hir \& Hily 2005) surrounding boulders. This factor can influence boulder species such as chitons (Liversage et al. 2012), and gastropods such as $N$. atramentosa may respond similarly. Recruitment of brachyuran crabs also can vary among cobbles, shell grit and algal turf (Pardo et al. 2007), which may vary between reef types. Such mechanisms may be involved in causing the different 
assemblages between reef types; the following experiments were used to test if specifically rock type was involved.

\section{Q2: Do assemblages on initially bare and unmanipulated boulders converge over time?}

Comparisons over time between mature assemblages on control boulders and developing assemblages on initially bare boulders provided an answer to Question 2, i.e. whether these assemblages would, within $11 \mathrm{mo}$, converge to become similar, rather than remaining distinct, as they were when initially bare boulders were first deployed. The only occasion when a difference was detected between control boulders and initially bare ones of the same rock type as the reef was for $N$. atramentosa on siltstone reefs, although it must be kept in mind there may be other differences that are simply not detectable (Chapman \& Underwood 1996, Chapman 2003). The greater abundances in mature compared to developing assemblages indicate that abundances of this species may take more time to reach mature levels or may remain different for reasons other than simply lack of developmental time, i.e. any reason for which alternative stable states develop (Samuels \& Drake 1997, Petraitis et al. 2009). But in general, assemblages on initially bare and unmanipulated boulders did develop similarly structured assemblages. This is not unexpected, since many mobile species migrate frequently amongst boulders (Liversage et al. 2012), and initially bare substrata is often colonised very rapidly (Chapman 2002, 2003, 2007).

\section{Q3: Do assemblages differ between rock types on the scale of individual boulders?}

It was interesting that most species had greater abundances in reefs of a certain rock type, but when boulders of both rock types were deployed within reefs, they were colonised in similar abundances by those same species. It is clear that processes acting on scales at the individual boulder level generally do not explain differences at the reef scale. A similar discrepancy between different scales of association of species with rock types has been found for turfing algae and oysters (Green et al. 2012) and tubeworms (McGuinness 1988). It does not appear that any studies have determined a cause for this discrepancy. The fact that it is being observed repeatedly suggests it would be worthy of further investigation.
The general trend among the macrofauna was of limited responses to rock type at the boulder scale. There was evidence, however, that one exception to this trend is the true limpet, Notoacmea spp., because this genus appeared to develop an association with siltstone at the scale of both reefs and individual boulders. A limpet's muscular foot represents a large proportion of soft tissue in contact with the substratum, and our results agree with predictions that such species should be display associations with certain rock types (Vermeij 1971). A mechanism causing this positive response to siltstone may have been the less rugose surface of this rock type or its fewer cracks and depressions relative to limestone. Shells of limpets need to fit the substratum closely (Lowell 1984), making features of the rock surface important. More heterogenous surfaces can inhibit movement (Chapman 2000) and tenacity (Grenon \& Walker 1981) and may cause Notoacmea spp. to behaviourally avoid these substrata, recruit less onto them or suffer greater mortality there. The species of Notoacmea found in these reefs were morphologically very similar, but because 3 species from this genus were grouped, some species-specific patterns may have not been evident.

\section{Q4: Does succession on siltstone and limestone differ at the level of reefs or boulders?}

Assemblage changes over time were mostly asynchronous and provided little evidence that successional trajectories diverged according to rock type. For populations of Notoacmea spp. on top of boulders, however, there was evidence of changing abundances in developing assemblages, consistent among locations, which appeared successional. Specifically, a significant peak in abundance occurred after 4 mo on siltstone boulders in limestone reefs, but abundances did not vary significantly over time for the other boulder and reef types, suggesting that successional dynamics can vary amongst contexts involving substrata.

Most studies of succession have investigated variability in processes related to disturbance (Sousa 1979, Rydgren et al. 1998, Platt \& Connell 2003) or season (Foster 1975, Zajac \& Whitlatch 1982). Much less is known about successional variation related to other abiotic variables that differ spatially or temporally in ways unrelated to disturbance or season. Variables concerning the substratum can be important, as demonstrated for a marine habitat in the present results and also previously in some terrestrial 
habitats (Donnegan \& Rebertus 1999). If species prone to competitive exclusion during succession are able to persist in areas with differing substrata, it may increase landscape-scale species diversity irrespective of variation in disturbance regimes. Factors involving rock type or substrata could potentially interact in complex ways with features of disturbance regimes, such as frequency and intensity, influencing succession and consequent patterns of species abundance and biodiversity.

Overall, we demonstrate that in these rocky intertidal reefs, assemblages are mostly not, at the boulder scale, associated with substratum features, but for some species, such associations may be complicated by only occurring at specific successional stages. Also, for species that do consistently change in abundance during succession, rock type can mediate the state of those changes. Increased awareness that successional processes may interact not only with factors involving disturbance but also with those involving other natural or anthropogenically influenced environmental factors will allow better detection of effects associated with those factors across complex landscapes.

Acknowledgements. We are grateful for geological guidance offered by C. Flaxman and V. Gostin (Adelaide University) and thank P. Fairweather, C. Fraser and A. Bugnot for advice on experimental design and statistical analysis. We are also grateful to our field volunteers S. Whitmarsh, T. Stewart, R. Baring, C. Sexton and T. Nguyen. This project was supported by an Honours scholarship to N.J. from the School of Biological Sciences, Flinders University, and a grant to K.B. from the Marine Ecology Research Centre, Southern Cross University. We thank P. Petraitis and 2 anonymous referees for providing suggestions on an earlier version of the paper.

\section{LITERATURE CITED}

Abelson A, Denny MW (1997) Settlement of marine organisms in flow. Annu Rev Ecol Syst 28:317-339

> Anderson TW (2001) Predator responses, prey refuges, and density-dependent mortality of a marine fish. Ecology 82 : 245-257

Anderson MJ, Underwood AJ (1994) Effects of substratum on the recruitment and development of an intertidal estuarine fouling assemblage. J Exp Mar Biol Ecol 184:217-236

Anderson MJ, Gorley RN, Clarke KR (2008) PERMANOVA+ for PRIMER: guide to software and statistical methods. PRIMER E, Plymouth

> Archambault P, Bourget E (1996) Scales of coastal heterogeneity and benthic intertidal species richness, diversity and abundance. Mar Ecol Prog Ser 136:111-121

Bavestrello G, Bianchi CN, Calcinai B, Cattaneo-Vietti R and others (2000) Bio-mineralogy as a structuring factor for marine epibenthic communities. Mar Ecol Prog Ser 193:241-249
Berntsson KM, Jonsson PR (2003) Temporal and spatial patterns in recruitment and succession of a temperate marine fouling assemblage: a comparison of static panels and boat hulls during the boating season. Biofouling 19: 187-195

Cabin RJ, Mitchell RJ (2000) To Bonferroni or not to Bonferroni: when and how are the questions. Bull Ecol Soc Am 81:246-248

> Chabot R, Bourget E (1988) Influence of substratum heterogeneity and settled barnacle density on the settlement of cypris larvae. Mar Biol 97:45-56

> Chalmer PN (1982) Settlement patterns of species in a marine fouling community and some mechanisms of succession. J Exp Mar Biol Ecol 58:73-85

> Chapman MG (2000) A comparative study of differences among species and patches of habitat on movements of three species of intertidal gastropods. J Exp Mar Biol Ecol 244:181-201

Chapman MG (2002) Early colonization of shallow subtidal boulders in two habitats. J Exp Mar Biol Ecol 275: 95-116

Chapman MG (2003) The use of sandstone blocks to test hypotheses about colonization of intertidal boulders. J Mar Biol Assoc UK 83:415-423

> Chapman MG (2007) Colonization of novel habitat: tests of generality of patterns in a diverse invertebrate assemblage. J Exp Mar Biol Ecol 348:97-110

$>$ Chapman MG, Underwood AJ (1996) Experiments on effects of sampling biota under intertidal and shallow subtidal boulders. J Exp Mar Biol Ecol 207:103-126

Clarke KR, Chapman MG, Somerfield PJ, Needham HR (2006) Dispersion-based weighting of species counts in assemblage analyses. Mar Ecol Prog Ser 320:11-27

Connell JH (1978) Diversity in tropical rain forests and coral reefs. Science 199:1302-1310

Davidson RJ, Chadderton WL (1994) Marine reserve selection along the Abel Tasman National Park coast, New Zealand: consideration of subtidal rocky communities. Aquat Conserv 4:153-167

> Dayton PK (1971) Competition, disturbance, and community organization: the provision and subsequent utilization of space in a rocky intertidal community. Ecol Monogr 41: 351-389

> Donnegan JA, Rebertus AJ (1999) Rates and mechanisms of subalpine forest succession along an environmental gradient. Ecology 80:1370-1384

> Drake DR, Mueller-Dombois D (1993) Population development of rain-forest trees on a chronosequence of Hawaiian lava flows. Ecology 74:1012-1019

Farrell TM (1991) Models and mechanisms of succession: an example from a rocky intertidal community. Ecol Monogr 61:95-113

Foster MS (1975) Algal succession in a Macrocystis pyrifera forest. Mar Biol 32:313-329

> Green DS, Chapman MG, Blockley DJ (2012) Ecological consequences of the type of rock used in the construction of artificial boulder-fields. Ecol Eng 46:1-10

> Grenon JF, Walker G (1981) The tenacity of the limpet, Patella vulgata L.: an experimental approach. J Exp Mar Biol Ecol 54:277-308

> Guichard F, Bourget E (1998) Topographic heterogeneity, hydrodynamics, and benthic community structure: a scale-dependent cascade. Mar Ecol Prog Ser 171:59-70

- Guidetti P, Cattaneo-Vietti R (2002) Can mineralogical features influence distribution patterns of fish? A case study 
in shallow Mediterranean rocky reefs. J Mar Biol Assoc UK 82:1043-1044

- Guidetti P, Bianchi CN, Chiantore M, Schiaparelli S, Morri C, Cattaneo-Vietti R (2004) Living on the rocks: substrate mineralogy and the structure of subtidal rocky substrate communities in the Mediterranean Sea. Mar Ecol Prog Ser 274:57-68

- Hansen PJ (2002) Effect of high pH on the growth and survival of marine phytoplankton: implications for species succession. Aquat Microb Ecol 28:279-288

Hasenohr P, Corbett D (1986) A field guide to the coastal geology of Fleurieu Peninsula. Gillingham Printers, Adelaide

> Herbert RJH, Hawkins SJ (2006) Effect of rock type on the recruitment and early mortality of the barnacle Chthamalus montagui. J Exp Mar Biol Ecol 334:96-108

> Holmes SP, Sturgess CJ, Davies MS (1997) The effect of rock-type on the settlement of Balanus balanoides (L.) cyprids. Biofouling 11:137-147

> Huston M, Smith T (1987) Plant succession: life history and competition. Am Nat 130:168-198

> Jackson AC (2010) Effects of topography on the environment. J Mar Biol Assoc UK 90:169-192

> James RJ, Underwood AJ (1994) Influence of colour of substratum on recruitment of spirorbid tubeworms to different types of intertidal boulders. J Exp Mar Biol Ecol 181: 105-115

Kuklinski P, Barnes DKA (2008) Structure of intertidal and subtidal assemblages in Arctic vs temperate boulder shores. Pol Polar Res 29:203-218

> Le Hir M, Hily C (2005) Macrofaunal diversity and habitat structure in intertidal boulder fields. Biodivers Conserv 14:233-250

Liversage K, Benkendorff K (2013) A preliminary investigation of diversity, abundance, and distributional patterns of chitons in intertidal boulder-fields of differing rock type in South Australia. Molluscan Res 33:24-33

Liversage K, Cole VJ, McQuaid CD, Coleman RA (2012) Intercontinental tests of the effects of habitat patch type on the distribution of chitons within and among patches in intertidal boulder field landscapes. Mar Biol 159: 2777-2786

> Lowell RB (1984) Desiccation of intertidal limpets: effects of shell size, fit to the substratum, and shape. J Exp Mar Biol Ecol 77:197-207

> Lubchenco J (1983) Littorina and Fucus: effects of herbivores, substratum heterogeneity, and plant escapes during succession. Ecology 64:1116-1123

McGuinness KA (1988) Explaining patterns in abundances of organisms on boulders: the failure of 'natural experiments'. Mar Ecol Prog Ser 48:199-204

McGuinness KA, Underwood AJ (1986) Habitat structure and the nature of communities on intertidal boulders. J Exp Mar Biol Ecol 104:97-123

> Pardo LM, Palma AT, Prieto C, Sepulveda P, Valdivia I, Ojeda FP (2007) Processes regulating early post-settlement habitat use in a subtidal assemblage of brachyuran decapods. J Exp Mar Biol Ecol 344:10-22

Moore HB, Kitching JA (1939) The biology of Chthamalus stellatus (Poli). J Mar Biol Assoc UK 23:521-541

> Nakagawa S (2004) A farewell to Bonferroni: the problems of low statistical power and publication bias. Behav Ecol 15:1044-1045

Editorial responsibility: Lisandro Benedetti-Cecchi, Pisa, Italy
Nelson BV, Vance RR (1979) Diel foraging patterns of the sea urchin Centrostephanus coronatus as a predator avoidance strategy. Mar Biol 51:251-258

Palmer MA, Ambrose RF, Poff NL (1997) Ecological theory and community restoration ecology. Restor Ecol 5: 291-300

> Petraitis PS, Methratta ET, Rhile EC, Vidargas NA, Dudgeon SR (2009) Experimental confirmation of multiple stable states in a marine ecosystem. Oecologia 161:139-148

> Pickett STA, Collins SL, Armesto JJ (1987) Models, mechanisms and pathways of succession. Bot Rev 53:335-371

> Platt WJ, Connell JH (2003) Natural disturbances and directional replacement of species. Ecol Monogr 73:507-522

Ponder W, Creese RG (1980) A revision of the Australian species of Notoacmea, Collisella and Patelloida (Mollusca: Gastropoda: Acmaeidae). J Malacol Soc Aust 4: 168-208

Raimondi PT (1988) Rock type affects settlement, recruitment, and zonation of barnacle Chthamalus anisopoma Pilsbury. J Exp Mar Biol Ecol 123:253-267

Rydgren K, Hestmark G, Okland RH (1998) Revegetation following experimental disturbance in a boreal oldgrowth Picea abies forest. J Veg Sci 9:763-776

Samuels CL, Drake JA (1997) Divergent perspectives on community convergence. Trends Ecol Evol 12:427-432

Schiaparelli S, Guidetti P, Cattaneo-Vietti R (2003) Can mineralogical features affect the distribution patterns of sessile gastropods? The Vermetidae case in the Mediterranean Sea. J Mar Biol Assoc UK 83:1267-1268

> Sousa WP (1979) Disturbance in marine intertidal boulder fields: the non-equilibrium maintenance of species diversity. Ecology 60:1225-1239

> Sousa WP (1984a) Intertidal mosaics: patch size, propagule availability, and spatially variable patterns of succession. Ecology 65:1918-1935

> Sousa WP (1984b) The role of disturbance in natural communities. Annu Rev Ecol Syst 15:353-391

Tomascik T, van Woesik R, Mah AJ (1996) Rapid coral colonization of a recent lava flow following a volcanic eruption, Banda Islands, Indonesia. Coral Reefs 15:169-175

Underwood AJ (1997) Experiments in ecology: their logical design and interpretation using analysis of variance. Cambridge University Press, Cambridge

Underwood AJ, Anderson MJ (1994) Seasonal and temporal aspects of recruitment and succession in an intertidal estuarine fouling assemblage. J Mar Biol Assoc UK 74: 563-584

> Underwood AJ, Chapman MG (1989) Experimental analysis of the influences of topography of the substratum on movements and density of an intertidal snail, Littorina unifasciata. J Exp Mar Biol Ecol 134:175-196

Underwood AJ, Jernakoff P (1981) Effects of interactions between algae and grazing gastropods on the structure of a low-shore intertidal algal community. Oecologia 48: 221-233

> Vermeij GJ (1971) Substratum relationships of some tropical Pacific intertidal gastropods. Mar Biol 10:315-320

> Wilding TA, Palmer EJ, Polunin NV (2010) Comparison of three methods for quantifying topographic complexity on rocky shores. Mar Environ Res 69:143-151

Zajac RN, Whitlatch RB (1982) Responses of estuarine infauna to disturbance. II. Spatial and temporal variation of succession. Mar Ecol Prog Ser 10:15-27

Submitted: January 17, 2013; Accepted: January 31, 2014

Proofs received from author(s): May 7, 2014 